other than for bows prior to the year 1550. It is likely, therefore, that the demand was so great that the better quality was becoming scarce, and even at that early date it was found necessary to import supplies from Spain.

It appears also that at a very early date it became fashionable to plant yew walks. One such walk still flourishes to-day at Huntington Castle, Clonegal, Ireland, and regarding this Mr. Manning Robertson writes to me under date of June 27, 1944, as follows :

"This consists of 122 trees in a row : the row is some 360 feet long and there are 'return ends' making three sides of a rectangle. The largest tree is 41 feet high and 12 feet 9 inches girth at 5 feet from the ground. Many of the trees have interlaced and grown together-like Bany'an trees. Little is known of the Walk's history, but it is almost certainly monastic, and tradition has given the age as 600 years : it is still in perfect condition."

Elwes mentions :

"a remarkably fine yew walk at Hatherop Castle, Gloucestershire ... which is supposed to be about 300 years old, in which the trees average about 60 feet in height with a girth of 9 to 12 feet."

The importance of the yew as hedgerow has been recognized for many centuries. Its use for the partition of fields has been debarred because of the danger to animals. Although it is slow in growing to perfection, as protection for property it has been for long ages justly prized, and is not only very decorative but also presents a formidable barrier, impossible to climb and very difficult to destroy.

John Evelyn evidently felt strongly on the question of yew hedges, as he wrote :

"the Yew tree has been generally cultivated for the pleasure garden, to be clipped into the shape of beasts, birds, etc., or for hedges. Whoever is pleased with such figures can raise no tree more proper for the purpose, as the branches and the leaves may be clipped and fashioned into almost any form or shape. But as this method is justly exploded, and as everyone who has the least pretension to taste, must always prefer a tree in its natural growth to those monstrous figures, the Yew is now chiefly planted for wilderness quarters, and for hedges, for which service it is excellently well adapted."

With regard to its uses for timber, and quoting from "The Timbers of the World" :

"This useful and highly decorative wood is now little known or esteemed, although it presents qualities which deserve much better recognition. If the economic use of domestic woods were practised in this country as it has been in France and Germany, yew would have undoubtedly been brought into prominence. The colour is pale red, somewhat like cherry wood or pencil cedar: it has a beautiful smooth lustrous grain. Sometimes it is handsomely figured, and occasionally has a burr growth, the produce of which will compare favourably with amboyna, and has indeed actually been mistaken for it. The strength and elasticity of yew-wood has been known for centuries, particularly on account of its use for bows. . . . At Sir Mark Collet's house, near Sevenoaks, some handsome doors are made of yew. The stiles and rails are of the ordinary figured wood, and the panels of exceptionally fine figured burr. The colour has deepened with long exposure, assisted by careful polishing, and is now a rich red brown. Yew is particularly suited fór chair-making, and some very fine specimens of considerable antiquity are to be found in many places. Elwes alludes to an extremely handsome arm-chair in Hornby Castle, the property of the Duke of Leeds. The date is about 1550. It is made of Yew, which adds to its rarity, for up to this time it was practically penal to employ yew-wood for any other purpose than the manufacture of the national weapon; in this instance the wood has become close, as hard as steel, and of a beautiful dark amber colour. The wood, though it is difficult to obtain, is also valued for brush-backs."

Yew is specially liable to the growth of 'burrs', which I have already mentioned. About thirty years ago an outstanding example was sent to me from the Caucasus, measuring more than seven feet in length, more than four feet in depth, and weighing nearly a ton. Purchased by an American, it was cut into veneer, yielding some of the finest specimens of yew burr ever seen.

It is difficult to decide whether this unique tree should be extensively cultivated; but it is certain that as a tree it has many interesting and unusual qualities, and as timber it is a fine medium for decorative work of all kinds.

\section{THE UNIVERSITIES AND INDUSTRY}

THE "Report on the Extension of Scientific Research in Manchester University, particularly in Relation to the Industries of its Area" (Manchester University Press, 1944, 1s.) which has been prepared by a committee of professors and industrialists, all of whom are members of the governing bodies of the Univorsity, to assist the University to make a considered estimate of the increase in income necessary to ensure that its science departments may undertake their proper responsibilities in the nation's economy, is of much more than local interest. In the first place, it amplifies some passages in the recent pamphlet of Sir Ernest.Simon on the development of British universities, while at the same time it offers some measure' of the value of the Joint Standing Council of members of the University of Manchester and the Manchester Chamber of Commerce which has been under discussion between the two bodies, as announced by Mr. A. H. S. Hinchliffe at the last of the series of meetings on "Science and Industry" arranged by the Chámber. Again, in its chapter on research and teaching, it puts concisely much of the argument advanced in the recent House of Commons debate, by the Parliamentary and Scientific Committee and elsewhere, and attempts to give concrete expression to the means by which those arguments may be given effect.

The statement includes detailed reports from the Chemistry and the Electro-Technics Departments, which have been chosen because of their relevance to some of the more important scientific industries of the area. The first of these reports comes from Dr. C. J. T. Cronshaw, Prof. A. R. Todd and Prof. M. Polanyi; and the second is by Dr. A. P. M. Fleming and Prof. Willis Jackson. The broad conclusion reached is that the effective discharge of the functions of the science departments of the University of Manchester in the post-war period involves doubling the expenditure of the Departments as a whole. Even this would provide for no new developments outside existing departments, and the report proposes an increase of about 50 per cent in the first year, rising to 100 per cent in the fifth year after the War.

In its introductory survey of research and teaching, the statement emphasizes that the primary duty of the science departments must be research at the highest levels of which they are capable. The first step towards improving teaching standards in any 
scientific department must be to increase the facilities for, and the volume and pace of, research. The expansion of research facilities in the science departments is thus placed first in order of importance ; it comes before the expansion of student numbers, because the standard of a university depends on it.

Deprecating the distinction between 'pure' and 'applied' research, the statement prefers to speak of 'academic' and 'industrial' research, distinguishing the different modifying and conditioning factors which surround the same intellectual process. The outlook, approach and method of the research worker are the same whether he is in a university or in industry. Development work, which is the conversion of results of research into processes of economic production, depends for its success on men in industry who combine scientific knowledge with experience of practical problems in their particular field. The statement suggests that the flow into industry of men who have graduated in a strong science department, who have learned as postgraduates an outline of research technique, and who keep in touch with the work of academic laboratories, will reduce very materially the time-lag between research and development. The real and permanent link between university science departments and industry is in research.

Pursuing this argument, the chapter on post-war development in chemistry, from its review of the development of chemical industry in Germany, argues that a first-class seientific industry cannot be built up in the absence of first-class universities which are teaching science; while, on the other hand, such universities cannot long continue to function in the absence of an industry capable of exploiting scientific developments and willing to employ scientific staffs trained in them. The organic chemical industry in the past has been built up on coal and can continue to be based on coal in spite of the threat of the natural oil fields seeking new outlets for their new materials; and the statement urges that without an intensive research effort, both by industry and by the universities, comparable with that taking place in the United States, the organic chemical industry in Great Britain will falter and a great natural asset, coal, will be playing a lesser part in world development than is its due share. Besides the plans for an increased flow from the university of research chemistsrepresenting in detail a department with an annual intake of fifty honours students and a total of some eighty research workers (including staff) - a flow from industry is recommended, such as the practice of releasing senior men in industry to pursue research in academic schools, for say two-year periods; and facilities for academic workers to visit other centres abroad for limited periods.

The following report, on post-war developments in electro-technics, similarly urges that what is particularly needed by the engineering schools is a scheme for the return, for limited periods, of selected men from industry. In the period between the two wars Great Britain lagged behind other industrial countries in the production for world consumption of those engineering goods and tools of production which result from the application of recent scientific and technical research and invention. This was a direct consequence of our inadequate research activity in the branches of science concerned, and in electrical engineering the effect was particularly marked on the telecommunications side. If, however, those university physicists and engineers who, either in their university departments or elsewhere, have contributed so much to the war-effort, are given comparable research facilities in the post-war period, the intimate liaison between university scientific workers and their industrial colleagues which has been established will develop to the great benefit of both the universities and industry, and of the country as a whole. Collaboration between the engineering schools and industry is particularly desirable in the attack on the border-line subjects between pure science and engineering, especially in the study of the properties of materials in relation to their chemical composition and physical structure.

With regard to the Manchester Department of Electro-technics, an increase in the number of undergraduate students to an average of twenty to twentyfive a year is suggested, and accommodation for up to ten men in each of two postgraduate courses. Even if some of the postgraduate teaching is conducted by part-time specialist lecturers from the local industry, the scheme will involve doubling the present full-time staff, with a further supplement to the laboratory staff. On a rough estimate, a further $£ 20,000$, based on pre-war costs, spread over the fiveyear period, will be required to bring the laboratories into a condition to initiate the scheme.

The statement does not touch on the question of a School of Chemical Engineering in Manchester raised by Sir Ernest Simon in his pamphlet. The spirit and trend of the statement, however, suggest that the Joint Standing Council at present under consideration may not only stimulate further the contact between the University of Manchester and the industries of the north-west of England, but also facilitate interregional consultation with regard to the founding of new schools where they will best serve national needs and not merely local interests or prestige.

\section{DEVELOPMENT OF THE CARIBBEAN REGION}

HE report of the West Indian Conference held at
Barbados during March 21-30, 1944 (Colonial No. 187. H.M. Stationery Office, 1944. 6d. net), contains accounts of the findings of the six committees which considered the agenda of the Conference. One of these specifically considered the Caribbean Research Council and possibilities for its expansion. In addition to the existing Sectional Committee on Agriculture, Nutrition, Fisheries and Forestry, the establishment of four further sectional committees is recommended, for public health and medicine, for industries, for building and engineering research, and for social sciences. Creation of a statistical unit to serve all sectional committees is recommended; and also early consideration by the Research Council of legal and fiscal problems related to collaboration among the research institutions of the Caribbean, with the view of submitting proposals to the Anglo-American Caribbean Commission for possible consultation with the Governments concerned.

Three general points are emphasized by the committee considering the Caribbean Research Council. First is the importance of freedom of action and independence of thought for the Research Council and its technical experts in the sectional committees, within the terms of reference specified by the AngloAmerican Caribbean Commission. The Research 